\title{
11: 104411067-104401445
}

National Cancer Institute

\section{Source}

National Cancer Institute. 11:104411067-104401445. NCI Thesaurus. Code C41822.

Physical location of CASP1_Gene 